\title{
The Medical Admissibility Provision vis-à-vis the Charter of Rights and Freedoms
}

\section{Valentina Capurri}

Since the initial formulation of a national immigration policy for the country in 1869, Canada has included a provision of inadmissibility on the grounds of mental and/or physical disabilities. Whereas the provision was created with the intention of excluding from Canada those subjects who were considered a risk to the genetic integrity of the nation or 'unemployable' because of their disability, with time the emphasis has shifted to focus on the excessive costs that the disease or disability would likely place on Canadian medical and social services, particularly after the passage of Medicare in 1968. The focus of this article will be on the provision as included in the Immigration Act of 1976 since only after the passage of the Charter of Rights and Freedoms in 1982 has the provision been questioned as discriminatory towards persons with mental or physical disabilities.

My goal in the following pages is to show the limitations as well as the potential of the Charter in addressing issues of discrimination against persons with disabilities who also happen to be immigrants (or potential immigrants) to the country. Because of what Aiken defines as "residual uncertainty regarding their status vis -à-vis the Charter," I have not discussed the situation of immigrants outside Canada, thus concentrating only on those who, for various reasons, have been able to reach the country. Indeed, when it comes to applicants who are outside Canada, there has been significant debate on whether they can claim Charter protection. According to several liberal immigration scholars, for example, it is still debatable "whether a community owes any duty to non-members or aspiring members who are still outside the community."2 As the following discussion demonstrates, "Canadian courts and jurisprudence have not exactly articulated this conflict" 3 either. Voyvodic and Iyioha believe that the conflict results from the presumption that foreigners seeking admission to Canada are not invested with 'rights' but are instead afforded or denied the 'privilege' of joining the Canadian family. ${ }^{4}$ By removing any discussion of rights from the immigration debate, liberal scholarship makes the latter immune to assessments based on justice criteria. Immigration law can therefore be considered more or less charitable or humanitarian, but it remains at all times outside the field of justice. $^{5}$

After a brief historical introduction on how disability came to be one of the protected grounds from discrimination in s. 15 of the Charter, I will discuss why this inclusion has not been considered by the courts when assessing whether the Canadian Immigration Act discriminates against immigrant appli- 
cants with disabilities. Through the analysis of the lawsuit brought forward by Dalijeet Singh Deol and the hearing of the Chesters case, I plan to show how the state has eluded accusations of discrimination partly, but not exclusively, by recourse to s. 1 of the Charter, the 'reasonable limits' clause, and to the overall tendency of the justice system to avoid interfering in the political process, particularly with respect to matters concerning immigration. My hope is that the ordeals experienced by Mr. Deol and Mrs. Chesters as described in the pages that follow will reveal to the reader how the lives of two human beings were subjected to a process of humiliation that at times resembled mockery and that hardly any Canadian citizen would find acceptable in a country referred to, on the domestic as well as international scene, as 'the land of rights and freedoms'.

The focus of my analysis is the Canadian Immigration Act of 1976 as it was the legislation in effect at the time the Charter was passed in 1982. The Act established that:

19. (1) No person shall be granted admission if he is a member of any of the following classes:

(a) persons who are suffering from any disease, disorder, disability or other health impairment as a result of the nature, severity or probable duration of which, in the opinion of a medical officer concurred in by at least one other medical officer,

(i) they are or are likely to be a danger to public health or to public safety, or

(ii) their admission would cause or might reasonably be expected to cause excessive demands on health or social services. ${ }^{6}$

It should be noted that the provision has remained almost unaltered in the subsequent Immigration and Refugee Protection Act that received Royal Assent on November 12001 , and is currently in place. This partly resulted from the general climate following the events of September 11th, when attention on the immigration front began shifting to issues of national security and the fight against 'terrorism'. Although the issue has sporadically received media attention, it appears that in the last decade Canadian society has been mostly concerned with keeping out criminal elements and has not spent much time thinking about immigrant applicants with non-communicable diseases or disabilities. On the other hand, the fact that the provision of medical admissibility has been upheld by the courts throughout the last twenty-five years has provided a rationale for not questioning it, thus making the courts complicit in its maintenance.

However, it is worthy of mention that the present law differs in one major respect from its predecessor as it eliminates the restriction if the immigrant applicant: 
(a) has been determined to be a member of the family class and to be the spouse, common-law partner or child of a sponsor within the meaning of the regulation;

(b) has applied for a permanent residence visa as a Convention refugee or a person in similar circumstances;

(c) is a protected person; or

(d) is, where prescribed by the regulations, the spouse, common-law partner, child or other family member or a foreign national referred to in any of paragraphs (a) to (c). ${ }^{7}$

Consequently, the medical admissibility criteria in the 2001 Act neither apply to spouses and children of Canadians/permanent residents nor to refugees. Leaving aside the issue of refugees, which would require a separate investigation, the change has originated in an effort to have the law conform to one of its long-standing objectives: family reunification. ${ }^{8}$ Yet, it would be worthwhile to analyze whether the change has resulted in a victory or a defeat for the applicant: is it really a satisfaction to be assessed not for who you are as an individual but for the person sponsoring you? I sincerely doubt that any of us would find any gratification in the thought that immigration authorities are more concerned with the right of a Canadian/permanent resident spouse to live with his/her partner than with our individual right to enjoy a productive and self-fulfilling existence in the country of our choosing. Whereas it is true that the family category is by definition assessing individuals as part of a family unit, we need to question the fact that while all adults have a choice whether to apply as independent or sponsored, this choice eludes those with an illness/disability.

In this article, I argue that in light of the principles embodied in s. 15 of the Canadian Charter of Rights and Freedoms, article 19(a)(ii) of the Immigration Act, 1976 (and its new version, art. 38(1)(c) of the Immigration and Refugee Protection Act) resulted in a policy that was discriminatory in the distinction it made between medically admissible persons and those who were not admissible because their health condition or disability might have posed an excessive demand on Canadian health and social services. I also offer explanation as to why such an argument has failed to receive endorsement from the courts, therefore allowing the state to continue discriminating against this particular equity-seeking group. Drawing on the Foucauldian discourse around biopolitics and state racism, I attempt to elucidate the reasons behind the maintenance of a virtual status quo in immigration legislation while other laws have been revised and amended to make them compliant with the Charter.

The Canadian Charter of Rights and Freedoms is part of the Constitution Act that came into force on April 171982 under the Liberal government of Pierre Elliott Trudeau. It replaced the Canadian Bill of Rights 
passed in 1960 by the Diefenbaker government; whereas the latter was not constitutionally entrenched and applied only to federal legislation, the Charter is part of the Constitution and therefore applies to the federal as well as provincial governments, also empowering the court system to review and invalidate any law that is contrary to it. For the first time in Canadian history, s. 15 (1) of the Charter unequivocally states that:

Every individual is equal before and under the law and has the right to the equal protection and equal benefit of the law without discrimination and, in particular, without discrimination based on race, national or ethnic origin, colour, religion, sex, age or mental or physical disability. ${ }^{9}$

Although part of the Constitution Act, the equality rights guaranteed by the Charter in s. 15 were put under a moratorium of three year (see s. 32(2) of the Charter) as the federal and provincial governments needed the time to review existing laws and amend them in case they conflicted with s. $15 .{ }^{10}$ Yet, as already mentioned, the Immigration Act was not among the laws to be reviewed and amended.

The Charter was reflective of a new attitude towards issues of equality and rights that went beyond the mere legal sphere to touch every aspect of society. The passage of the Charter, and in particular its s. 15, represents a milestone for the recognition of rights for persons with disabilities within Canadian society. Sarah Armstrong explains that the Charter "became the first constitution to guarantee a right to equality for persons with disabilities."11 And yet, when s. 15 was introduced in Parliament in October 1980, it made no reference to persons with disabilities. The exclusion was strongly opposed by the disability community on three different fronts: in the media and in public debates over patriation, in discussions of the Special Committee of the House of Commons on the Disabled and the Handicapped, also known as the Parliamentary Handicap Committee, and in presentations to the Special Joint Committee of the Senate and House of Commons on the Constitution of Canada (the Hays-Joyal Committee). ${ }^{12}$ While the disability community advocated for the constitutional recognition of the right to equality for persons with disabilities, the federal government actively resisted the idea of having mental and physical disability added to s. 15. Minister of Justice Jean Chrétien argued that there were three main objections to including the disabled among the protected groups. First, the courts were already in a position to intervene if a person with disability was discriminated. Second, there was no clear definition in Canadian society of who were those covered by the term disability. Finally, there was no real need to protect disability rights under the constitution as the provinces already had effective human rights codes. ${ }^{13}$ Another objection never clearly stated but always hinted at, was that it would be too expensive to fund new services that might be 
required by the Charter. However, "[a]t no point did the government present statistical or factual support for the claim that including disability in section 15 would cost too much money." 14 Before the Hays-Joyal Committee, several organizations such as the Coalition of Provincial Organizations of the Handicapped $(\mathrm{COPOH}),{ }^{15}$ the Canadian Association for the Mentally Retarded (CAMR) and the Canadian National Institute for the Blind (CNIB) contested the government's position. They argued that "the cost argument was untenable, first, because the argument itself was unsupported ... and, second, because disability was the only ground of discrimination to which this cost-benefit analysis was being applied." 16 A similar argument is applicable to the medical admissibility provision in the Immigration Act of 1976 and in the current Immigration and Refugee Protection Act. Ireh Iyioha refers to several research studies indicating that despite the persistence of the common view that immigrants are depleting Canadian healthcare resources, they are actually underutilizing them. ${ }^{17}$

In the fight to have disability included in the Charter, it certainly played to the advantage of the disability rights' advocates that the debate took place in the United Nations International Year of Disabled Persons. Yvonne Peters recalls that Canada had been one of the co-movers of the United Nations resolution that had designated the year 1981 as the International Year of Disabled Persons. ${ }^{18}$ Equally significant, the theme chosen for the UN International Year of Disabled Persons was "Equality and Full Participation."19 Given these premises, it became difficult to justify the refusal to entrench the rights of persons with disabilities into the new Constitution while at the same time supporting the principles of full participation and equality entrenched in the United Nations resolution. ${ }^{20}$ In the end, the government capitulated and on January 281981 "Canada added both mental and physical disability to the list of specifically protected groups in sections 15(1) and 15(2) of the Charter." 21 Providing persons with disabilities with constitutional recognition of their right to equality magnified their impact on society. For the first time, they found themselves in possession of a new legal tool in the quest for equality. Armstrong remarks that "[s]ince the enactment of the Charter, groups representing people with disabilities have repeatedly intervened in equality rights cases to persuade the courts to adopt this vision of substantive equality." 22 Although the courts have not always adopted a progressive view of the Charter (and here 'progressive' refers to the active protection of minority rights that are overlooked in the ordinary process of majoritarian democracy), it remains true that it has been extremely empowering to finally have a voice in the Supreme Court. ${ }^{23}$ Indeed, Armstrong notes that " $[t]$ he potential for interest advocacy under the Charter has given disability groups significant new opportunities to influence the development of the law and public opinion on fundamental disability issues." 24 If recourse to the courts 
has rarely presented persons with disabilities with the expected outcomes, it has nonetheless given them a resource to reach out to and has created a lively debate within the broader society. Whereas I agree with Mandel that the Charter, born under the auspices of transferring power to the people, has most often merely transferred power to those in the legal profession, ${ }^{25} \mathrm{I}$ also believe that its reach has gone beyond the legal sphere, thus making it a document Canadians celebrate as symbolic of their identity.

At its most basic the Charter has allowed advocacy groups and individuals to use the document as a legal tool in the courts in order to advance their claims since 1985. In the 1989 decision in Andrew v. Law Society of British Columbia, the Supreme Court of Canada, in the person of Justice McIntyre, ruled that the Charter's protection extends to persons who are neither Canadian citizens nor permanent residents. In explaining the ruling, McIntyre "maintained that non-citizens are a minority group analogous to those enumerated under the grounds of s. 15 and that they come within the protection of s. $15 . " 26$ The Court decision opened a new avenue for immigrant applicants to fight those provisions of the Immigration Act that were discriminatory. In particular, the Charter appears to have the potential for strongly impacting the medical admissibility provision. While it is true that its application is restricted to the Canadian territory, ${ }^{27}$ it should be noted that several individuals applying to permanently immigrate are already in Canada, for instance holders of working or study visa permits and individuals who have received a ministerial permit. Whereas claims of discrimination by private individuals or groups are usually handled under statutory human rights laws, discrimination by government (such as government laws and policies) is under the purview of the Charter and human rights acts. ${ }^{28}$ Given the significance of the Charter for the advancement of disability rights within the country, it is important to reflect on the way it has been used in the courts by advocacy organizations and those directly affected by the medical admissibility provision.

This article originated in an investigation I conducted as part of my doctoral thesis on the historical development of public discourse around immigrant medical admissibility in Canada. My work explored the public discourse entertained by different societal actors such as Parliament, the press, and the judicial system; one of the chapters analyzed several court cases related to the medical admissibility provision contained in the Canadian Immigration Act of 1976 and their relation to the Charter of Rights and Freedoms. ${ }^{29}$ By examining how these cases were presented and discussed in courts, I intended to demonstrate that the provision in question was discriminatory and unconstitutional under s. 15 of the Canadian Charter of Rights and Freedoms. I was also attempting to shed light on the policy adopted by the state on the subject of 
medically inadmissible immigrants. In order to investigate the role played by the Charter in questioning the section of the Immigration Act dealing with potential immigrants considered inadmissible due to health conditions or disabilities, I decided to focus on seventeen cases brought to the Federal Court and the Supreme Court of Canada by the plaintiffs to contest the Immigration Department's decision to refuse them or their family members' entrance into the country. The earliest lawsuit among those investigated was heard in May 1988 while the latest was heard in February 2005. Two of the cases reached the Supreme Court. All others were dealt with by the Federal Court of Canada. ${ }^{30}$

At the beginning of the investigation, I expected that most of the cases would directly engage with s. 15 of the Charter. After all, the equality clause is the first to come to mind when dealing with issues of discrimination by the government against individuals belonging to equity seeking groups. It was therefore puzzling to find out that only two of the seventeen cases made explicit reference to the Charter while all the others contested the decision without actually questioning the existing law; in each instance, the plaintiff merely argued that the provision did not apply to the specific situation under review. Despite the initial ambiguity, I believe that there is a subtle connection between the way the cases were conducted and the Charter. It appears likely that faced with the argument repeatedly put forth by the defense and accepted by the courts that the medical admissibility clause does not refer to persons with disabilities but focuses instead on excessive demand, the plaintiffs were forced to shift their focal point away from disability and concentrate their attention on showing they were not likely to pose excessive demand on Canadian health and social services. In so doing, while contesting in a tangential way the discriminatory nature of the legislation under the Charter, the core of their argument eluded the issue. Furthermore, it should be considered that Charter cases are expensive and rarely successful, therefore the silence around the Charter could be also explained as a simple litigation strategy. Finally, as previously noted, the application of the Charter to 'foreigners' is contested in the academy as well as in the legal domain, this constituting a disincentive for claimants.

The only two exceptions to this trend were represented by the lawsuit brought forward by Dalijeet Singh Deol in 1992 and by the hearing of Angela Chesters in 2001. For this reason, both cases are analyzed in this paper. The Deol case touches on the Charter only tangentially but deserves mention, as it constitutes one of the first direct references to the Charter in a court proceeding dealing with immigration to Canada. The Chesters hearing is the most significant and groundbreaking since Mrs. Chesters maintained that the medical admissibility provision was unconstitutional as it offended s. 15 of the Charter in discriminating against persons with disabilities. Although unsuccessful, the hearing is of paramount importance to understanding the potential impact the Charter might 
have on the way the Canadian state relates to inadmissible immigrant applicants.

On November 25 1992, the Federal Court of Appeal in the person of Justices MacGuigan, Linden and Robertson, heard the case of Deol v. Canada (Minister of Employment and Immigration). The appeal was directed against the decision of the Immigration and Refugee Board dismissing a previous appeal from the immigration officer's refusal of a sponsored application. In that circumstance, the appellant's mother and her two dependant daughters had been refused entrance into Canada on the grounds that one of the daughters was diagnosed with mental retardation and could reasonably be expected to cause excessive demands on health and social services. The appellant contested the Board's decision on the basis of both validity and equity. In the judgment delivered on November 27 1992, Justice MacGuigan allowed the appeal and ordered the matter returned to a differently constituted panel for rehearing and redetermination. While recognizing that the Board cannot question a medical diagnosis, MacGuigan declared, "it should inquire into the reasonableness of their [the medical officers'] conclusion as to the probable demands on government services. In the case at bar ...... the Board did not inquire into the reasonableness of the medical officers' conclusion, but rather assumed ... that the conclusion was reasonable." 31

In contesting the validity of the Board's decision, the appellant also argued that the Board was wrong in establishing that the onus of proof had to be placed on the applicant. Given that mental retardation was a form of mental disability and therefore was an enumerated ground of discrimination under s. 15(1) of the Charter, Deol maintained that any justification had to be made under s. 1 of the Charter, which reads:

The Canadian Charter of Rights and Freedoms guarantees the rights and freedoms set out in it subject only to such reasonable limits prescribed by law as can be demonstrably justified in a free and democratic society. 32

Accordingly, Deol claimed that the onus was on the government. Deol's claim rested on the understanding that any limitations to the rights and freedoms guaranteed by the Charter must be justified by the party asserting it, namely the federal or provincial government. If indeed the onus remained on the citizen, he or she would have, as pointed out by the Honourable Fogarty, to literally "fight for his or her rights" 33 and this would make the Charter a useless instrument and the intended protection of the rights and freedoms of individuals a mere pretence. ${ }^{34}$ Justice MacGuigan rejected the argument since it contradicted s. 8(1) of the Immigration Act, which explicitly placed the burden of proof on the person seeking entrance into Canada. Nevertheless, the court decided to allow the 
appeal as the Board failed to take into account the nature and degree of the mental retardation as well as humanitarian and compassionate considerations such as "close bonds of affection that may arise in such a family." 35 In so doing, the Board ignored the intention of the Immigration Act to facilitate family reunification.

Deol v. Canada is significant in the context of this article insofar as the appellant made a direct albeit minor reference to s. 15 of the Charter. Justice MacGuigan acknowledged that the issue had never before been argued in front of the court. However, in a questionable decision, he maintained that the contention was inconsequential as s. 8(1) of the Immigration Act had precedence over the Charter. As shown in the following pages, while the Charter is an integral part of the Canadian constitution and is therefore, as clearly stated in s. 52(1) of the Constitution Act, the most important law in the country, the courts have often acted erratically in their conclusions. They have refused to acknowledge the incongruity existing between the Charter and several of Canada's laws. Particularly with respect to immigration, the courts' unwillingness to examine whether immigration policy conforms to principles of universal justice, has allowed the state to operate under what Voyvodic defines as "wasteland."36 Similarly, Agamben refers to 'state of exception', a blind juridico-institutional spot where the state can ignore its own laws in the name of 'necessity'. ${ }^{37}$ In the case under study, the state continues excluding immigrant applicants with disabilities although the exclusion patently violates its commitment to non-discrimination on grounds of disability. The courts appear complicit in this process of discrimination as their lack of acknowledgment of such violation only helps in legitimizing it.

As noted above, almost all of the immigration lawsuits brought to court in those years failed to make direct reference to the Canadian Charter of Rights and Freedoms. Instead of questioning the law as unconstitutional because in violation of s. 15 of the Charter, the litigations simply cast doubts on the correctness of applying the medical admissibility provision to the specific circumstances of the appellants. It is curious that at a moment when "the Charter has invigorated the struggles of groups that represent people with disabilities,"38 references to the Charter were absent in the overwhelming majority of legal cases dealing with individuals who had been refused admission into Canada because of mental or physical disabilities. Most likely this occurred because legal counsels were of the opinion that questioning the constitutionality of the Immigration Act was not going to be successful in court. In fact, there were two major obstacles to overcome: the government's claim that the issue at stake was not disability but excessive demands created by disability, and the fact that s. 1 of the Charter establishes that rights and freedoms guaranteed by the Charter itself are not 
unconditional but subject to reasonable limits (and again, what is or is not reasonable is a matter of interpretation) prescribed by the law.

Equally important is to consider that, as pointed out by Evelyn Kallen in Ethnicity and Human Rights in Canada, "individuals or organizations bringing complaints under the Charter must pay for the costs involved." 39 Recognizing that costs can be prohibitive, especially for persons belonging to disadvantaged minorities, the federal government had initially set aside some funding for "selected 'Charter Challenge' court cases at the federal level. However, this program was discontinued in 1992." 40 While axed by the Conservative Mulroney government, the program was revived by the Liberals when they came to power in 1993. However, after being criticized for years by social conservatives and critics of judicial activism for providing groups with the money to go to court and thus circumvent the will of Parliament, the program has since then been killed once again in the fall of 2007 by the Conservative government of Stephen Harper. As a result, many persons have been prevented from pursuing the option of using the Charter for the protection and recognition of their rights. The high costs involved in bringing Charter claims forward have made the document inaccessible to those needing it most. If not for the subsidies provided by organizations advocating on issues of rights and equity, and the benevolence of some lawyers to bankroll cases, the Charter would remain a luxury many cannot afford.

Despite these difficulties, in 2001 Angela Chesters, a German citizen married to a Canadian, challenged as unconstitutional the visa officer's decision to refuse her permanent resident status under the 'family class' category on the basis that she had multiple sclerosis (MS) and was therefore likely to cause excessive demands on health and social services. Her case represents the first serious attempt at questioning the medical admissibility provision contained in the Immigration Act as unlawful because it violation of s. 15 of the Charter. It is also noteworthy because of the publicity it received and the debate it generated in Canadian society at large. The fact that the effort to prove the unconstitutionality of the Act did not succeed speaks volumes about the way Canadian law approaches issues of immigration and disability. It further reveals some of the limitations of the Charter on the issue of equality rights. At the same time readers should keep in mind that as unique and remarkable as it is, Angela Chesters' case highlights a state policy on immigrants with disabilities that has been at work for more than a century and has affected a large number of people who have remained anonymous, never getting the attention of the media or Canadian society more widely. The focus should therefore remain on a long-lasting process of exclusion rather than on a single figure of note. 
In December 1991, Angela Chesters, a German citizen holding Masters' degrees in both History and Science and Information Technology, married Robin Chesters, a native of South Africa who had subsequently acquired Canadian citizenship. In September of that year, Mrs. Chesters was diagnosed with MS and by the end of 1993 she was using a wheelchair. At that time, the couple lived in England. In 1994, they decided to move to Canada and Mrs. Chesters submitted an application for permanent residence as a member of the family class. On 14 November 1994, Robin Chesters received a telephone call from Mr. Ernest Alston, visa officer at the Canadian High Commission in London (where Angela had submitted her application) informing him that his wife had been determined to be medically inadmissible to Canada under s. 19(1)(a)(ii) of the Immigration Act. Mr. Alston advised Mr. Chesters to investigate the possibility of obtaining a ministerial permit allowing Mrs. Chesters to enter the country. Under a ministerial permit (today's Temporary Resident Permit), immigrants are allowed to enter and remain in the country for a limited period of time usually not exceeding three years. By then, the couple was already living in Canada since Mrs. Chesters had received a visitor's visa in the summer 1994. In April 1995, Angela Chesters was issued a ministerial permit valid for three years. The following year, however, she moved back to Germany to work and was joined by her husband in February 1999. After receiving a negative response from immigration authorities, Mrs. Chesters did not pursue an application for judicial review but decided to challenge the constitutionality of $\mathrm{s}$. 19(1)(a)(ii) by way of action. This was done through the issuance of a statement of claim on April 21997 (an amended statement was filed on July 29 of the same year). ${ }^{41}$

Angela Chesters commenced her action in 1997. On August 30 2000, the Minister of Citizenship and Immigration made an offer in writing to settle the proceeding, which included landing for the plaintiff. However, on September 27 2000, Mrs. Chester rejected the offer believing that it had been made to silence her and avoid having the court assess the constitutionality of the provision. On the basis that the offer had not been accepted, the court dismissed the claim advanced by Citizenship and Immigration Canada (CIC) that the issue before the court was moot, as there was no 'live controversy' between the parties to the litigation. The rationale behind the dismissal is that the court has competence to resolve legal disputes within an adversarial system and this cannot be done without the existence of a true adversarial context. In spite of this, the court still has authority to hear a case when the latter involves collateral consequences for the litigants. The court can also refuse dismissal when there is an intervener with a stake in the outcome of the litigation. As pointed out by Justice Dawson, there were valid reasons for the court to hear the case brought forward by Angela Chesters. Dawson noted that the plaintiff's request was for a 
102 Capurri

declaration that s. 19(1)(a)(ii) was inconsistent with s. 7 and s. 15 of the Charter. Hence,

While at the end of the day the plaintiff certainly may hope to be landed (and I note parenthetically to be landed by right and not by the defendant's largesse as reflected in a settlement offer), it remains that the plaintiff's action does not directly put landing in issue and is not limited to a claim for landing. 42

In December 2001, CIC asked for summary judgment and repeated its request to have the issue declared as moot since a new Immigration and Refugee Protection Act had been given Royal Assent on November 12001 (though it had not yet come into force). According to the new Act, Mrs. Chesters "would no longer be medically inadmissible under subsection 38(2) of the new legislation." 43 In fact, the section referred to by CIC establishes that the medical admissibility provision does not apply to persons who are refugees or spouses, common law partners or children of a Canadian citizen or permanent resident. After due consideration, Justice Lufty dismissed the motion once again on the grounds that:

The plaintiff's action is grounded on the current legislation, not on the new Immigration and Refugee Protection Act which has yet to come into force. In his letter to the Court dated December 4, 2001, counsel for the plaintiff stated that the new legislation has no impact on this litigation. $^{44}$

In refusing to have the case dismissed for mootness, the court also considered that, by order dated February 20 2001, Prothonotary 45 Lafreniere granted intervener status to the Council of Canadians with Disabilities (CCD), a national not-for-profit organization representing persons with disabilities. On February 27 2001, the CCD made a written submission to the court arguing that it was important to adjudicate on the issue of constitutionality of s. 19(1)(a)(ii) since the provision contributed "to the pervasive negative stereotype of persons with disabilities, including those who are permanent residents of Canada, as a drain on society." 46 The organization maintained that for years the Department of Citizenship and Immigration had attempted to avoid having the constitutionality of the Act adjudicated in court by issuing ministerial permits to individuals who had initiated a Charter challenge. The consequence had been that " $[\mathrm{t}]$ hose who are desperate for permanent status in Canada usually do not have the resilience to see a case through its conclusion when tempted by the blandishment of a Minister's Permit." 47 The department's successful attempts in terminating litigations had resulted in the continuation of a practice that was discriminatory at its roots. Accordingly, the CCD insisted: 
The issue at the core of this case: the constitutionality of section 19(1)(a) of the Act, is regarded by the CCD as an issue of national importance. This is not only because of its impact on persons with disabilities from abroad, who would be welcomed as new Canadians were it not for their disability; but of equal importance is its discriminatory impact upon Canadians with disabilities who are stigmatized by this legislation's failure to recognize that disabled people make contributions to Canadian society. ${ }^{48}$

On June 27 2002, in her submissions to the court, Angela Chesters argued that she was discriminated against on the basis of her medical condition "which was improperly categorized by Canadian immigration officials as a disability." 49 She therefore challenged the constitutionality of s. 19(1)(a)(ii) on the grounds that it contravened s. 7, guaranteeing life, liberty and security of the person, and s. 15 of the Charter. According to Mrs. Chesters, s. 7 was violated because she was placed in a situation of uncertainty which resulted in high levels of mental and psychological stress. More importantly, s. 15 was offended as she had been singled out as belonging to a class of persons who were explicitly protected by that section. She maintained that even "if the provision is not discriminatory on its face, then it still breaches the guarantee of equality because it has an adverse discriminatory effect. It improperly impacts upon a distinct group of people who are already vulnerable to discrimination." 50 Mrs. Chesters' arguments were also adopted by the intervener, the Council of Canadians with Disabilities. Additionally, the CCD submitted that the medical admissibility provision was "further flawed by failing to address the potential contribution to be made to Canada by persons suffering from disabilities." 51

In presenting its case, CIC maintained that s. 19(1)(a)(ii) did not offend s. 7 and s. 15 of the Charter and was, in any event, justifiable under s. 1. Canada had both the right and obligation to set standards for entry into the country, and subparagraph 19(1)(a)(ii) was meant to accomplish that objective by protecting Canadian health and social services against excessive demands. CIC denied Mrs. Chesters' claim that the department's actions had resulted in a breach of s. 7 of the Charter since levels of stress are to be assessed objectively and that section was never intended to "protect an individual from the ordinary anxiety that would be felt by a person of reasonable sensibility, as the result of government action." 52 As for s. 15 of the Charter, CIC relied on a previous decision reached in 1999 by the Supreme Court in Law v. Canada Minister of Citizenship and Immigration) where the court identified three steps to be followed when assessing whether s. 15 of the Charter had been breached. The first step was to look at an appropriate comparator group receiving a different treatment from the plaintiff. Whereas Angela Chesters argued that a distinction had been made between able- 
104 Capurri

bodied and disabled spouses of Canadian citizens who applied for permanent residence, $\mathrm{CIC}$ responded that the distinction to be considered was the one between persons who were medically admissible and those who were not. The second step consisted in assessing whether the distinction had been based upon the enumerated grounds of disability. Contesting Chesters' argument, CIC stated that the distinction had no relation to disability but was exclusively based on the concept of 'excessive demands'. Finally, the third step looked at discrimination based on stereotypical reasoning. CIC argued that the plaintiff was "assessed on a personalized basis" 53 and therefore there had been no stereotypical reasoning behind the visa officer's rejection.

In giving the reasons for the court order, Justice Heneghan began by stating that "[i]t is well-settled law that not every differential treatment gives rise to discrimination." 54 He then proceeded to assess whether discrimination had taken place in the case brought forward by Angela Chesters. For that purpose, he heavily relied on the three steps process outlined in Law v. Canada Minister of Citizenship and Immigration) and previously referred to by the respondent. On the question of a proper comparator group, Justice Heneghan concluded that Mrs. Chesters had sought admission to Canada as member of the family class; accordingly, the family class and not able-bodied spouses of Canadian citizens was the appropriate comparator group. Accepting the department argument, the court interpreted s. 19(1)(a)(ii) as focusing on excessive demands rather than disability. Justice Heneghan pointed out, "[s]ubparagraph 19(1)(a)(ii) is not directed to any of the specified grounds in subsection 15(1) of the Charter. It is directed to excessive demands." 55 The Act had the purpose of protecting Canada against excessive demands and "that purpose is apparent even if the words "disease", "disorder" or "disability" are deleted." 56 Justice Heneghan's reasoning for choosing the family class as comparator group appears questionable. Dale Gibson explains that, under Charter jurisprudence, the "ambit of the comparison group is ... no longer capable of being defined by the law itself" 57 (in this case, the Canadian Immigration Act), but depends on "who is complaining and what they are complaining about." ${ }^{58}$ It is quite clear that Angela Chesters was not complaining about the law itself but the way it was applied to a subgroup of the applicant population, namely persons with disabilities. As remarked by Justice McIntyre in Andrew v. Law Society of British Columbia, to ignore that a similar treatment can actually result in the discrimination of certain individuals, ${ }^{59}$ is deceitful at best.

Remarking that entry into Canada is a privilege rather than a right, Justice Heneghan concluded, 
The section in question focuses on excessive demands, not on disease, disorder or disability. Contrary to the stance taken by the plaintiff, this case is not about disability but the medical assessment of potential immigrants to Canada within the context of Canadian immigration law. By its nature, legislation governing immigration must be selective... The process of assessing medical examinations for the purpose of determining excessive demands upon existing Canadian health services is an aspect of the screening process ... In my opinion, this is not within the enumerated grounds of subsection 15(1) nor is it analogous to it. 60

With respect to the plaintiff's claim that the actions of the state had put her in a situation of uncertainty, which resulted in high levels of psychological stress, thus contravening the guarantee of life, liberty and security of the person under s. 7 of the Charter, the court dismissed the argument as well. Stating, "the constitutional guarantee of security of the person does not protect against 'ordinary stresses and anxieties that a person of reasonable sensibility would suffer as a result of government action',"61 the court decided that,

the plaintiff's right to security of the person was not infringed in consequence of the application of the inadmissibility section. She was not the victim of state action. As a potential immigrant, she was subject to meeting the requirements of the Immigration Act and Regulations. ${ }^{62}$

Accordingly, the action was dismissed as "subparagraph 19(1)(a)(ii) offends neither subsection 15(1) of the Charter nor section 7." 63

The court did not address any of the submissions presented by the intervener, the Council of Canadians with Disabilities. In particular, the court failed to address the intervener's criticism that the medical admissibility provision did not balance the potential contributions to Canadian society of persons with disabilities or illnesses against expected costs to health and social services. On that issue, Justice Heneghan chose to remain silent. Sarah Armstrong observes that several scholars have repeatedly indicated that the judicial system is inherently conservative and the courts are more likely to uphold the status quo than validate a progressive interpretation of the Charter. ${ }^{64}$ This occurs in particular when decisions are related to immigration. ${ }^{65}$ Catherine Dauvergne maintains that "migration decision-making" is characterized by both "[e]xecutive discretion and judicial deference," this being demonstrated by "the scant impact which the Canadian Charter of Rights and Freedoms has had on immigration and refugee law." 66 The court decision in the case of Angela Chesters confirms Dauvergne's interpretation. On the other hand, in a number of cases, the courts have played a significant role "in safeguarding minority rights overlooked in the ordinary 
106 Capurri

processes of majoritarian democracy." 67 While the assumption that "once the rights of people are enshrined in Canada's Charter of Rights and Freedoms, they are implemented as a matter of course" 68 is patently false, I am convinced that the Charter represents a valuable tool in the advancement and protection of minority rights within the judicial system. With reference to individuals with mental or physical disabilities, their inclusion in s. 15 of the Charter has represented a victory in their struggle for recognition. More importantly, it has finally given them a voice.

It is also interesting to note that, as it emerges in the 2002 decision in Chesters v. Canada, the question of excessive demands is still asked exclusively in relation to immigrant applicants with diseases or disabilities despite the fact that other groups as well could potentially result in high costs for the Canadian economy. In giving its judgment in the Chesters' case, the court maintained that the medical admissibility provision was not discriminatory as its intention was to protect the state against the possibility of excessive demands created by some individuals. In particular, the court pointed out that the purpose of the provision was evident whether or not explicit references to disease, disorder or disability were made in its wording. However, the court's argument was flawed as it failed to consider that, should those words be deleted, the provision could be used to keep out of the country also heavy drinkers, smokers or aged people, all categories that could likely be expected to pose excessive demands on health and social services. The court's rationale did not account for the fact that the Department of Citizenship and Immigration appears to pay no attention to such categories while it keeps focusing on individuals with diseases and/or disabilities.

This paper has presented two cases illustrating the way the Charter has been used in the courts to contest the medical admissibility provision contained in the Canadian Immigration Act of 1976. In so doing, it has demonstrated that to date the argument that the provision is incompatible with the Charter and should therefore be revised, has not resonated well with the courts. Looking in particular at the reasoning provided by the judicial system in dismissing the action brought forward by Angela Chesters, there seem to be two possible explanations for the court's refusal to consider the provision in violation of the Charter. The first and most simplistic explanation is the one presented by CIC in the Chesters case, namely that the provision in question does not refer to disability but focuses on the issue of excessive demand. The court accepted this reasoning and, in the words of Justice Heneghan, maintained that "[s]ubparagraph 19(1)(a)(ii) is not directed to any of the specified grounds in subsection 15(1) of the Charter. It is directed to excessive demands." 69 Accordingly, the provision would stand "even if the words "disease", "disorder" or "disability" are deleted."70 Such an argument has little credibility since, as previously noted, 
should those words be deleted, the provision could also be used to keep out of the country other groups likely to pose excessive demands on health and social services. Instead, the Department of Citizenship and Immigration has decided to focus exclusively on individuals with diseases and/or disabilities. As long as a convincing justification for this targeting of a specific group continues to be missing, both the government's argument and the court validation of it are groundless.

The second possible explanation for ignoring the accusation of unconstitutionality of the medical admissibility provision is based on a more complex rationale. In can be summarized by arguing that the application of the Charter is not without limits. Indeed, s. 1 makes clear that rights and freedoms guaranteed by the Charter are subject to "such reasonable limits prescribed by law as can be demonstrably justified in a free and democratic society." 71 It could be argued that limits are reasonable and demonstrably justified in the case of potential immigrants who are expected to pose excessive demands on the system. However, there are two major problems with this argument. First, as noted by the Honourable Fogarty, "[t]he term "reasonable" presents a vague concept."72 According to the Webster Dictionary, reasonable means "being in accordance with reason," 73 but this still does not help in assessing whether or not excluding persons with diseases or disabilities from immigrating to the country is actually in accordance with reason any more than accepting heavy drinkers or smokers. Secondly, the reference to a limit that is "demonstrably justified" also raises several questions. The use of the term "demonstrably" indicates that the onus of justifying the limit is on the government (in this case, on the Department of Citizenship and Immigration). Yet, as pointed out in 1992 by Jerome Di Giovanni, then Secretary of the Canadian Disability Rights Council, during his intervention in front of the Parliamentary Committee created to discuss Bill C86, A Measure to Amend the Immigration Act, "No government, be it Conservative or Liberal, has ever managed to demonstrate that disabled persons were an excessive burden on Canadian society." 74 As of today, Di Giovanni's statement remains true. Consequently, as the limits imposed on the rights and freedoms guaranteed by the Charter to immigrants with diseases or disabilities have not been demonstrably justified, s. 1 cannot be called upon in dismissing claims of unconstitutionality of the medical admissibility provision.

As I have tried to demonstrate, the courts have erred in their interpretation of the Charter when dealing with claim of unconstitutionality of the medical admissibility provision. Different Justices have so far been quite reluctant to address questions of unconstitutionality, thus confirming the arguments of various scholars who maintain the judicial structure tends to uphold intact the existing system. ${ }^{75}$ It would be worthwhile to conduct a thorough examination of the 
reasons behind such a stance, beginning with considering to what extent this is a reaction to accusations repeatedly addressed to the courts of attempting to bypass the democratic process and reverse Parliament's decisions. Michael Mandel, for example, refers to judges as "elected by and accountable to nobody. Not only accountable to nobody, but also lacking any formal restraints." 76 Allan C. Hutchinson accuses judges and lawyers of being "a professional elite that can have no claim to constitutional priority over democratic deliberation."77 According to Hutchinson, constitutional supremacy has resulted in judicial supremacy, thus bringing Charter issues out of the "political forum of democratic debate and into the legal arena of judicial pronouncement." 78 The most detrimental outcome of this process is the decrease in active participation among the population, with citizens transformed into passive subjects. ${ }^{79}$ Although in a more nuanced form, Manfredi appears to share this view when suggesting that "[w] might be better off rediscovering the value of the public realm of politics" 80 rather than expecting the judiciary to solve all of society's problems around issues of liberty, equality and social justice. Unfortunately, while containing elements of truths, especially with respect to the contentions that any legal interpretation is political and that so far courts' decisions have not been particularly progressive, ${ }^{81}$ the argument against juridical intervention looks weak.

Hutchinson's call for "dialogic democracy," 82 an alternative space where tensions can be recomposed through negotiation between the parts, seems utopic at best as it fails to give due consideration to the fact that the players involved have different degrees of power, making the field decidedly uneven.

This paper has also revealed the state policy on the issue of medically inadmissible immigrants. It has shown that, even within the context of the Charter, the decision to reject those individuals who are not healthy and 'fully functional' according to society's standards continues to stand. The question therefore is: how is it possible that the state successfully ignores its own laws? In order to answer this question it is important to situate the discussion around immigration within the Foucauldian discourse of biopolitics and state racism. In "The Child-Citizen," Xiaobei Chen reminds the reader that "[b]iopolitical logics are premised on a conception of a population as a mass of living beings whose existence and well being are of fundamental concern to the state." 83 As explained by Foucault, the focus of biopolitics is "the population as a political problem." 84 Within this framework, illness holds a central place insofar as it is understood as "phenomena affecting a population." 85 On the other hand, the state uses state racism to "pose questions of biopower and sovereign power at the same time - determining who is to be excluded, rejected or removed - as to improve the happiness and health of the population." 86 If, following Agamben's argument, we admit that "Western politics is a biopolitics from the very begin- 
ning," and that this renders futile "any attempt to found political liberties in the rights of the citizens," 87 we must recognize that such a statement applies even more to those who lack citizenship and are still perceived as foreigners. It becomes therefore apparent that exclusion of certain subjects gets justified by the state as a process that must take precedence over any other laws, even over the constitution of the land. Under this logic, the medical admissibility provision is perfectly justified and cannot be questioned by recourse to the Charter.

As shown by the case of Angela Chesters and by the analysis in this paper, the Charter's application in the courts is no panacea. The judiciary tends to have a very conservative approach to the equality clause and appears inclined to uphold the status quo while the state continues to have a somewhat ethically questionable but still unchallenged argument. Nevertheless, the Charter represents a revolutionary tool in the hand of minority groups. With respect to the issue dealt with in this paper, the applicability of the Charter to every person who is on Canadian soil, no matter whether Canadian or not, has a potential that has not yet been fully explored and exploited. In particular, it brings into relief the issue of human rights guaranteed to every individual irrespective of nationality. In 1951, Hannah Arendt wrote in The Origins of Totalitarianism that, "general human rights, as distinguished from the rights of citizens" "proved to be unenforceable." 88 Arendt's argument has recently been echoed by Giorgio Agamben who maintains that the notion of human rights "is inconceivable in the law of the nation-state," 89 and that there are no rights outside those bestowed upon citizens. The Charter seems to represent the first serious attempt to invalidate such arguments. Whereas still tied to the notion of a nation state (as the document is enforceable only within the Canadian sovereign space), the fact that it applies to every human being physically in Canada without consideration for the individual's nationality, renders the Charter a revolutionary tool of unprecedented proportions. The refusal of the court in 2002 to engage with the criticism brought forward by the Council of Canadians with Disabilities is visible proof that many of the implications of the Charter have so far simply been disregarded.

However, disregard is not dismissal. These same issues will likely resurface again, and sooner or later the court will be forced to face them.

\section{NOTES}

1 Sharryn J. Aiken, "From Slavery to Expulsion: Racism, Canadian Immigration Law, and the Unfulfilled Promise of Modern Constitutionalism," in Interrogating Race and Racism, ed. Vijay Agnew (Toronto: University of Toronto Press, 2007), 74.

2 Ireh Iyioha, "A Different Picture Through the Looking-Glass: Equality, Liberalism and the Question of Fairness in Canadian Immigration Health 
110 Capurri

Policy," Georgetown Immigration Law Journal, Vol. 22 No. 4 (2008), 628.

3 Ibid., 628.

4 Ibid., 638. Rose Voyvodic, "Into the Wasteland: Applying Equality Principles to Medical Inadmissibility in Canadian Immigration Law," Journal of Law and Social Policy, Vol. 16 (2001), 115-116.

5 Iyioha, "A Different Picture Through the Looking-Glass," 640.

6 Immigration Act, 1976, S.C. 1976-1977, c. 52, s. 19 (1)(a).

${ }^{7}$ Immigration and Refugee Protection Act, S.C. 2001, c. 27, s.38 (2).

8 Marika Willms, "Canadian Immigration Law \& Same-Sex Partners," Canadian Issues/Thèmes Canadiens (Spring 2005), 17.

${ }^{9}$ Canadian Charter of Rights and Freedoms, Part I of the Constitution Act, 1982, being Schedule B to the Canada Act 1982 (U.K.), 1982, c.11.

${ }^{10}$ Honourable Kenneth H. Fogarty, Equality Rights and their Limitations under the Charter (Toronto: Carswell, 1987), 131.

11 Sarah Armstrong, "Disability Advocacy in the Charter Era," University of Toronto J. of Law and Equality, Vol. 2 No. 1 (2003), 35.

12 Ibid., 53.

13 William Boyce et al., A Seat at the Table: Persons with Disabilities and Policy Making (Montreal: McGill-Queen's University Press, 2001), 53.

14 Armstrong, "Disability Advocacy in the Charter Era," 53.

15 In 1994, the Coalition of Provincial Organizations of the Handicapped changed its name to Council of Canadians with Disabilities.

16 Armstrong, "Disability Advocacy in the Charter Era," 54.

17 Iyioha, "A Different Picture through the Looking-Glass", 659-60.

18 Yvonne Peters, "From Charity to Equality," in Making Equality, Deborah Stienstra and Aileen Wight-Felske (Toronto: Captus Press), 131.

19 Boyce, A Seat at the Table, 51.

20 Peters, "From Charity to Equality," 132.

21 Armstrong, "Disability Advocacy in the Charter Era", 55.

22 Ibid., 56.

23 Ibid., 77.

24 Ibid., 78.

25 Michael Mandel, The Charter of Rights and the Legalization of Politics in Canada (Toronto: Thompson Educational Publishing, 1994), 3.

26 Evelyn Kallen, Ethnicity and Human Rights in Canada (Toronto: Oxford University Press, 1995), 279.

27 Recently, the application of the Charter to only those already in Canada has been questioned by some scholars, Iyioha among others. See Iyioha 657.

28 Kallen, Ethnicity and Human Rights in Canada, 261. 
29 Valentina Capurri, "Canadian Public Discourse around Issues of Inadmissibility for Potential Immigrants with Diseases and/or Disabilities, 19022002" (PhD dissertation, York University, 2010).

30 The Federal Court has two levels: the Federal Court Trial Division and the Federal Court of Appeal. With respect to immigration matters, the Federal Court Trial Division has jurisdiction to hear applications for judicial review of immigration decision. Its judgment can then be appealed to the Federal Court of Appeal and the latter's decision can be further appealed to the Supreme Court. 31 Deol, Daljeet Singh v. M.E.I. (F.C.A. no. A-280-90) [1992], at para.5 and para. 6, MacGuigan, Linden, Robertson, (QL).

32 Charter.

33 Fogarty, Equality Rights and their Limitations under the Charter, 96.

34 Ibid., 95.

35 Deol, supra note 9 at para. 13.

36 Voyvodic, "Into the Wasteland," 142-43.

37 Giorgio Agamben, State of Exception (Chicago: The University of Chicago Press, 2005), 2-5.

38 Armstrong, "Disability Advocacy in the Charter Era", 37.

${ }^{39}$ Kallen, Ethnicity and Human Rights in Canada, 261.

${ }^{40}$ Ibid.

41 Chesters v. Canada (Minister of Citizenship and Immigration), [2002] FCJ No. 992, 115 A.C.W.S. (3d) 603, Heneghan J. (QL).

42 Chesters v. Canada (Minister of Citizenship and Immigration), [2001] FCJ No. 1135, 107 A.C.W.S. (3d) 292 at para. 21, Dawson J. (QL).

43 Chesters v. Canada (Minister of Citizenship and Immigration), [2001] FCJ No. 1849, 110 A.C.W.S. (3d) 901 at para. 4, Lufty J. (QL).

44 Chesters v. Canada (Minister of Citizenship and Immigration), [2001] FCJ No. 1849, 110 A.C.W.S. (3d) 901 at para. 13, Lufty J. (QL).

45 The prothonotary is the chief clerk of the court in certain courts of law; the office usually exists in places of Anglo-American jurisdiction.

46 Chesters v. Canada, Written Submissions of the Intervener, No. IMM-1316-97, Federal Court Trial Division, 27 February 2001.

47 Chesters v. Canada, Written Submissions of the Intervener.

48 Chesters v. Canada, Written Submissions of the Intervener.

49 Chesters v. Canada (Minister of Citizenship and Immigration), [2002] FCJ No. 992, 115 A.C.W.S. (3d) 603 at para. 50, Heneghan J. (QL).

50 Chesters v. Canada (Minister of Citizenship and Immigration), [2002] FCJ No. 992, 115 A.C.W.S. (3d) 603 at para. 62, Heneghan J. (QL).

51 Chesters v. Canada (Minister of Citizenship and Immigration), [2002] FCJ No. 992, 
115 A.C.W.S. (3d) 603at para. 65, Heneghan J. (QL).

52 Chesters v. Canada (Minister of Citizenship and Immigration), [2002] FCJ No. 992, 115 A.C.W.S. (3d) 603 at para. 75, Heneghan J. (QL).

53 Chesters v. Canada (Minister of Citizenship and Immigration), [2002] FCJ No. 992, 115 A.C.W.S. (3d) 603 at para. 91, Heneghan J. (QL).

54 Chesters v. Canada (Minister of Citizenship and Immigration), [2002] FCJ No. 992, 115 A.C.W.S. (3d) 603 at para. 100, Heneghan J. (QL).

55 Chesters v. Canada (Minister of Citizenship and Immigration), [2002] FCJ No. 992, 115 A.C.W.S. (3d) 603 at para. 122, Heneghan J. (QL).

56 Chesters v. Canada (Minister of Citizenship and Immigration), [2002] FCJ No. 992, 115 A.C.W.S. (3d) 603 at para. 111, Heneghan J. (QL).

${ }^{57}$ Dale Gibson, The Law of the Charter: Equality Rights (Toronto: Carswell, 1990), 79.

58 Ibid.

59 Voyvodic, "Into the Wasteland," 118 and Christopher Manfredi, Judicial Power and the Charter: Canada and the Paradox of Liberal Constitutionalism (Don Mills, Ontario: Oxford University Press, 2001), 124.

60 Chesters v. Canada (Minister of Citizenship and Immigration), [2002] FCJ No. 992, 115 A.C.W.S. (3d) 603 at para. 125 and para. 128, Heneghan J. (QL).

61 Chesters v. Canada (Minister of Citizenship and Immigration), [2002] FCJ No. 992, 115 A.C.W.S. (3d) 603 at para. 130, Heneghan J. (QL).

${ }^{62}$ Chesters v. Canada (Minister of Citizenship and Immigration), [2002] FCJ No. 992, 115 A.C.W.S. (3d) 603 at para. 131, Heneghan J. (QL).

63 Chesters v. Canada (Minister of Citizenship and Immigration), [2002] FCJ No. 992, 115 A.C.W.S. (3d) 603 at para. 139, Heneghan J. (QL).

64 Armstrong, "Disability Advocacy in the Charter Era," 77-83.

65 Voyvodic, "Into the Wasteland," 115, 128, 130.

66 Catherine Dauvergne, "Sovereignty, Migration and the Rule of Law in Global Times," Modern Law Review, vol.67, issue 4 (July 2004) 591.

67 Armstrong, "Disability Advocacy in the Charter Era," 46.

68 Parin Dossa, Racialized Bodies, Disabling Worlds (Toronto: University of Toronto Press, 2009), 66.

${ }^{69}$ Chesters v. Canada (Minister of Citizenship and Immigration), [2002] FCJ No. 992, 115 A.C.W.S. (3d) 603 at para. 122, Heneghan J. (QL).

70 Chesters v. Canada (Minister of Citizenship and Immigration), [2002] FCJ No. 992, 115 A.C.W.S. (3d) 603 at para. 111, Heneghan J. (QL).

71 Charter.

${ }^{72}$ Fogarty, Equality Rights and their Limitations under the Charter, 99. See also Manfredi, Judicial Power and the Charter: Canada and the Paradox of Liberal 
Constitutionalism, 39.

73 Merriam-Webster online Dictionary, online: http://www.merriam-

webster.com/dictionary/reasonable.

74 Bill C-86/Projet de loi C-86, 4:88.

75 Aiken, "From Slavery to Expulsion," 59. See also Mandel, The Charter of Rights and the Legalization of Politics in Canada, 69.

76 Mandel, The Charter of Rights and the Legalization of Politics in Canada, 2.

77 Allan C. Hutchinson, Waiting for Coraf: A Critique of Law and Rights (Toronto:

University of Toronto Press, 1995), 22.

78 Ibid., 24.

79 Ibid., 153.

80 Manfredi, Judicial Power and the Charter: Canada and the Paradox of Liberal

Constitutionalism, 199.

81 Hutchinson, Waiting for Coraf, 56, 121.

82 Hutchinson, Waiting for Coraf, 206.

83 Xiaobei Chen, "The Child-Citizen," in Recasting the Social in Citizenship, Engin F. Isin ed. (Toronto: University of Toronto Press, 2008), 182.

${ }^{84}$ Michel Foucault, Society Must Be Defended. Lectures at the Collège de France, $1975-$ 1976 (New York: Picador, 2003), 245.

85 Ibid., 244.

86 Chen, "The Child-Citizen," 182.

87 Giorgio Agamben, Homo Sacer: Sovereign Power and Bare Life (Stanford: Stanford University Press, 1998), 181.

88 Hannah Arendt, The Origins of Totalitarianism (New York: Harcourt Brace Jovanovich, 1973), 293.

89 Agamben, Means Without Ends (Minneapolis: University of Minnesota Press, 2000). 